International Journal of Instruction

e-ISSN: 1308-1470 • www.e-iji.net

Article submission code:

20210106192136

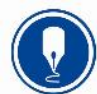

October $2021 \bullet$ Vol.14, No.4

p-ISSN: 1694-609X

pp. 585-606

Received: 06/01/2021

Revision: 07/04/2021
Accepted: 01/05/2021

OnlineFirst: 11/08/2021

\title{
The Impact of Distance Learning on the Psychology and Learning of University Students during the Covid-19 Pandemic
}

\section{Hesham Alomyan}

University of Petra, Jordan, halomyan@uop.edu.jo

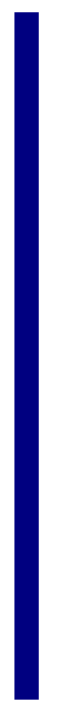

COVID-19 saw the world face a serious global health crisis which had a negative impact on all sectors of life especially education. Educational institutions across the globe were forced to temporarily close and use distance education as an alternative to face-to-face teaching. The current study explored the impact of the sudden transition from face-to-face learning to distance learning on students' psychology and learning. Four hundred and one $(\mathrm{N}=401)$ undergraduate students from the University of Petra, Jordan were surveyed using a user-designed online questionnaire. Results highlighted negative impacts of distance education on both participant's psychology and learning during the Covid-19 pandemic. More specifically, results showed that first and second year students and those with lower computer skills reported the highest negative psychological effects (i.e., feeling anxious, bored and nerves). Further first-year students and those with lower computer skill levels reported a negative impact on learning (i.e., experiencing lethargy and laziness when taking online lectures, poor focus and inability of being self-reliant when learning) by distance education when compared with students in their third and fourth year or those with higher and average computer skills. Finally, this paper discusses recommendations and implications for future distance learning.

Keywords: distance learning, online learning, psychological effects, Covid-19, students

\section{INTRODUCTION}

On March 11, 2020 the World Health Organization (WHO) declared Covid-19 a serious global health concern and pandemic (Cucinotta \& Vanelli, 2020). The fast spread of this virus globally impacted all aspects of life including education. Containing the spread of this deadly virus was foremost in the minds of all governments across the globe resulting in temporary shutdowns of educational institutions. Effecting more than $70 \%$ of the world's student population, educational institutions were forced to search for alternatives that could be employed to maintain continuity of education (Giovannella, 2021). In response to the universities closure, UNESCO recommended the use of online learning applications and platforms that enabled universities and teachers to communicate with learners and maintain the progress of student's education (UNESCO, 2020).

Citation: Alomyan, H. (2021). The impact of distance learning on the psychology and learning of university students during the covid-19 pandemic. International Journal of Instruction, 14(4), 585606. https://doi.org/10.29333/iji.2021.14434a 
In Jordan, the first case of Covid-19 was confirmed on March 2, 2020 (Serrieh, 2020). On March 14, 2020, Jordan imposed strict measures to combat the outbreak of the virus including closing all borders; banning all incoming and outgoing flights; and closing schools and universities. Following this decision, schools and universities moved to distance learning using various online learning applications and platforms (e.g., Google classroom, Zoom, Microsoft Teams, BlackBoard, Moodle, Facebook and WhatsApp). The closure of educational institutions in Jordan and the use of distance learning remain in effect at time of writing this paper.

Although distance learning has been around for many years, in the past few decades it has seen important developments (Akther, 2013), especially with the advent of the Internet. Educational institutions around the world have been competing to implement technology in teaching and learning, but there is no full implementation of distance learning in their educational process. Before the Covid-19 pandemic, most universities employed open learning platforms that complemented face-to-face teaching and learning (Dhawan, 2020) with on-campus university students not having experienced fully online learning. When Covid-19 hit, everything was shut down and universities found online learning applications as a safer form of continuing the educational process. However, shifting suddenly from face to face learning to distance learning created challenges and concerns for students and instructors including a sudden loss of socialization and interaction, poor internet connectivity, and selecting the most appropriate online tools. The objective of the present study therefore is to investigate the impact of these challenges and concerns related to distance learning on the psychology and learning of university students. Gaining insights into the potential challenges that students face will inform future online teaching practices as we continue to be challenged by Covid-19.

\section{Literature Review}

The sudden and forced adoption of distance learning following the spread of Covid-19 forced universities worldwide to search for effective technologies to secure the educational process and engage faculty and students in the process (Toquero, 2020). However, it must be acknowledged that most conventional universities and students were not fully prepared for using such technologies leaving them with a range of challenges (Crawford et al., 2020; Prokopenko \& Berezhna, 2020).

One of the main challenges that students encounter in distance learning is the loss of face-to-face interaction (Dzakiria, Idrus, \& Atan (2005). It is known that interaction in a normal educational setting occurs between the learner, instructor and content. However, the use of online learning applications and tools makes the interaction more complex. That is, students in distance learning need to take quizzes, exams, complete assignments, and interact with their instructors and peers using various technological tools, which some students lack the skills and ability to deal with, thus negatively impacting their learning.

Loss of socialization in distance learning is another major concern. In this mode of learning, students only interact with each other digitally, which potentially affects sharing of ideas and knowledge (Britt, 2006). In addition, lack of socialization has been 
found to leave some students experiencing psychosocial problems such as anxiety and depression (Elmer \& Stadtfeld, 2020; Mantasiah et al., 2021). A survey conducted in March, 2020 among higher education students in the United States of America showed that $75 \%$ reported experiencing anxiety and depression because of the isolation of distance learning (UNESCO, 2020). A study conducted by Irawan, Dwisona, and Lestari (2020) found that students at Mulawarman University in Indonesia experienced anxiety and boredom while learning at a distance during the Covid-19 pandemic and experienced mood changes due to the multitude of tasks required of them.

Another challenge that students face centres on internet connectivity. We cannot assume that all students have effective internet connections especially those from low-income families. Adnan and Anwar (2020) found that 51.6\% of the students in their study reported bad internet connectivity with $11.1 \%$ considered Internet services too expensive. In a survey conducted among 39,854 students at Southeast University in China students complained about the instability of the Internet connection, making them less enthusiastic and successful in distance learning (Sun, Tang \& Zuo, 2020).

Most research on distance learning has been conducted in conventional learning settings (Ahmad \& Al-Khanjari, 2011; Ali \& Ahmad, 2011; Carvalho, Areal \& Silva, 2010; Oliveira, Cunha, \& Nakayama, 2015; Yildiz, Tezer \& Uzunboylu, 2018; Zainuddin, Idrus \& Jamal, 2016), where online learning is used as a complementary tool to augment the conventional learning and teaching. Most of these studies documented challenges faced by students including additional work and reluctance of faculty members to implement online learning in their courses. Although students were satisfied with this mode of learning they preferred face-to-face learning coupled with online material and activities.

Research conducted on stand-alone distance learning systems (e.g., Attri, 2012; Dodo, 2013; Musingafi et al., 2015; Sharath, 2014), revealed that despite distance learning being more accessible and affordable, students continue to face challenges that affect their learning. These challenges include lack of sufficient time for study, insufficient ICT skills, lack of timely feedback on students' assignments and examinations, and unavailability of technical support.

Due to the Covid-19 pandemic, all conventional universities worldwide were required to implement, in a short period of time, distance learning methodologies. Recent studies have investigated the challenges and concerns associated with distance learning during the pandemic (Li et al., 2020; Mailizar et al., 2020; Moawad, 2020; Prokopenko \& Berezhna, 2020). For example, in Italy, Giovanella (2020) investigated the effects of switching the educational processes from physical to completely virtual on university students during the Covid-19 pandemic. The results revealed that although students appeared to miss their lectures and face-to-face activities, the sudden switch from faceto-face to virtual learning was positively received indicating that students can accept online learning when managed correctly.

In the Ukraine, Prokopenko and Berezhna (2020) conducted a study to determine the difficulties faced by university students while learning from a distance during the 
pandemic. The researchers identified several problems that had an impact on a student's psychological wellbeing including a lack of face-to-face interaction, missing practical lessons, a significant increase in assignments, and lack of time to complete tasks. Similarly, in Saudi Arabia, Moawad (2020) analysed student's worries and fears at the King Saud University amid the Covid-19 pandemic. The results showed that $32 \%$ of these students were concerned about how they will be assessed and the nature of the online final exam. Internet connectivity and associated fees impacted $17 \%$ of these students while others had problems with the use of online platforms. Difficulties with learning and taking lectures from a distance affected $16 \%$ of these students.

In China, Li, Cao, Leung, and Mak (2020) collected data on the mental health of college students during Covid-19. Findings revealed that year-two students had a higher negative effect and higher levels of anxiety and depression than year-one students. The researchers attributed this to the fact that the second-year curriculum was more compact than the first-year curriculum. Consequently, second-year students reported feeling afraid that quarantine and having to learn solely via the Internet would impede their progress in their studies.

In conclusion, it appears that the sudden move from conventional learning to distance learning during the Covid-19 pandemic coupled with the lack of experience in working with many technological tools on the part of students resulted in them experiencing various problems and concerns, which seemingly affected their learning. Thus, it must be acknowledged that students' perspectives on learning at a distance are important for the quality and improvement of distance learning. Future research should investigate students' perceptions on distance learning to further examine potential challenges that might hinder the achievement of learning goals and to make distance learning a better learning environment from their perspective. As a contribution to the research effort in this matter, the present study investigates the impact of distance learning on university students' psychology and learning during the Covid-19 pandemic.

\section{Research Questions}

The present research was undertaken to answer the following questions:

1. What is the impact of distance learning on the psychology of university students in Jordan during the Covid-19 pandemic?

2. What is the impact of distance learning on university students' learning in Jordan during the Covid-19 pandemic?

3. Are there significant differences in the impact of distance learning on the psychology of students attributable to gender, discipline, GPA, academic year, computer skills and distance learning device?

4. Are there significant differences in the impact of distance learning on students' learning attributable to gender, discipline, GPA, academic year, computer skills and distance learning device?

5. Is there a relationship between students' psychology and learning in distance learning during the Covid-19 pandemic? 


\section{METHOD}

\section{Participants}

Employing purposive sampling yielded four hundred and fifteen $(N=415)$ undergraduate students (291 females and 124 males), enrolled in various educational programs offered by the University of Petra. All members of the study sample participated in answering the questionnaire items. Consequently, 415 responses were returned. Table 1 shows participants' demographic information.

Table 1

Participants' demographic information

\begin{tabular}{llll}
\hline Variable & Category & Frequency & Percentage \\
\hline Gender & Male & 124 & 29.9 \\
& Female & 291 & 70.1 \\
\hline Discipline & Humanities & 151 & 36.4 \\
& Sciences & 264 & 63.6 \\
\hline GPA & Satisfactory & 40 & 9.6 \\
& Good & 144 & 34.7 \\
& Very good & 186 & 44.8 \\
& Excellent & 45 & 10.8 \\
\hline Academic year & First & 84 & 20.2 \\
& Second & 130 & 31.3 \\
& Third & 101 & 24.3 \\
& Fourth & 100 & 24.1 \\
\hline Distance learning & Computer & 166 & 40.0 \\
device & Mobile Phone & 242 & 58.3 \\
& Tablet/iPad & 7 & 1.7 \\
\hline Computer skill & High & 102 & 24.6 \\
levels & Average & 235 & 56.6 \\
& Low & 78 & 18.8 \\
\hline
\end{tabular}

\section{Instrument}

The study instrument was a user-developed online questionnaire that explored the impact of distance learning on the psychology and learning of undergraduate students during the Covid-19 pandemic. The questionnaire consisted of two parts: part 1 captured general demographic information; and part 2 contained the questionnaire items. The questionnaire items were distributed over two dimensions: dimension 1 gathered data on the psychological aspect of the students; and dimension 2 collected data on the educational aspect of the students. A five-point Likert scale was employed, where answers took the gradation of strongly agree, agree, neutral, disagree, strongly disagree with weightings of 5, 4, 3,2,1 respectively. All the questionnaire items were formulated in the negative form except items $8,12,13$ and 14 of the educational dimension that were formulated negatively and took weights $1,2,3,4$ and 5 . That is, the higher the mean of the answers the greater the negativity of distance learning.

The class width formula was used to divide the scale into three levels of equal length, which in turn indicated the degree of agreement, whether for each item of the scale or a 
group of items (dimension) and the three levels are (low, average, high). This was calculated according to the following equation:

Scale range $=($ Highest score - lowest score $) \div$ Number of levels

Scale range $=(5-1) \div 3=1.33$

Based on the above calculation the judgment on the degree of approval will be as shown in Table 2.

Table 2

Classification of degree of agreement

\begin{tabular}{ll}
\hline Class & Degree of agreement \\
\hline $1.00-2.33$ & Low \\
\hline $2.34-3.67$ & Average \\
\hline $3.68-5.00$ & High \\
\hline
\end{tabular}

\section{Validity of the instrument}

To ensure the instrument's validity six faculty members from the University of Petra and the University of Jordan in the field of educational technology were asked to assess the linguistic integrity of the items, clarity of their content, and their ability to achieve the study objectives. The faculty members' comments and suggestions were considered and changes were made to some of the questionnaire items. The factor validity of the instrument was verified by performing a factor analysis on the study variables with results being shown in Table 3. It is noted from the results of the factor analysis that the values of the latent root of all factors were higher than the value 1 , and all of them explained $60.632 \%$ supporting the validity of the instrument.

Table 3

Results of the factor analysis of the study variables

\begin{tabular}{lllll}
\hline $\begin{array}{l}\text { Factor } \\
\text { Number }\end{array}$ & $\begin{array}{l}\text { Value of the latent } \\
\text { root }\end{array}$ & Explained variance & $\begin{array}{l}\text { Cumulative } \\
\text { value }\end{array}$ & explanatory \\
\hline 1 & 13.039 & $43.463 \%$ & $43.463 \%$ \\
\hline 2 & 2.432 & $8.105 \%$ & $51.568 \%$ \\
\hline 3 & 1.563 & $5.212 \%$ & $56.780 \%$ \\
\hline 4 & 1.156 & $3.852 \%$ & $60.632 \%$ \\
\hline
\end{tabular}

The Pearson Correlation Coefficient was used to verify the validity of the internal consistency of the study instrument by finding the correlation coefficients for each item of the instrument with the total score of the dimension to which it belongs. Tables 3 and 4 illustrate these results. 
Table 4

Pearson Correlation Coefficients for each item of the psychological effects dimension with the total degree of the dimension

\begin{tabular}{ll}
\hline Item No & Correlation coefficient of items with the total score of the dimension \\
\hline 1 & $0.781^{*}$ \\
\hline 2 & $0.828^{*}$ \\
\hline 3 & $0.850^{*}$ \\
\hline 4 & $0.638^{*}$ \\
\hline 5 & $0.791^{*}$ \\
\hline 7 & $0.734^{*}$ \\
\hline 8 & $0.835^{*}$ \\
\hline 9 & $0.836^{*}$ \\
\hline 10 & $0.801^{*}$ \\
\hline 12 & $0.860^{*}$ \\
\hline 13 & $0.351^{*}$ \\
\hline 14 & $0.578^{*}$ \\
\hline
\end{tabular}

* Correlation is significant at (0.01).

It is clear from Table 4 that all the correlation coefficients of the items with the total degree of the psychological effects dimension are positive and statistically significant and ranged between (0.351-0.860), indicating that they were suitable for the purposes of the study, and the strength of the internal coherence of the study instrument.

Table 5

Pearson Correlation Coefficients for each item of the educational effects dimension with the total degree of the dimension

\begin{tabular}{ll}
\hline Item No & Correlation coefficient of items with the total score of the dimension \\
\hline 1 & $0.779^{*}$ \\
\hline 2 & $0.743^{*}$ \\
\hline 3 & $0.824^{*}$ \\
\hline 4 & $0.823^{*}$ \\
\hline 5 & $0.763^{*}$ \\
\hline 7 & $0.803^{*}$ \\
\hline 8 & $0.655^{*}$ \\
\hline 9 & $0.308^{*}$ \\
\hline 10 & $0.117^{*}$ \\
\hline 11 & $0.533^{*}$ \\
\hline 12 & $0.739^{*}$ \\
\hline 13 & $0.418^{*}$ \\
\hline 15 & $0.565^{*}$ \\
\hline 16 & $0.586^{*}$ \\
\hline
\end{tabular}

* Correlation is significant at (0.01). 
It is clear from Table 5 that all correlation coefficients of the items with the total degree of the educational effects dimension are positive and statistically significant and ranged between (0.142-0.860), indicating that they are suitable for the current study, and the strength of the internal coherence of the study instrument.

\section{Stability of the instrument}

The stability of the study instrument was confirmed by the Cronbach Alpha Coefficient. Table 6 shows that the total stability of the psychological effects dimension was 0.937 and the educational effects dimension was 0.853 . The total stability among all items across the two dimensions was 0.940 . These stability factors indicated the stability of the study instrument and its suitability for the current study.

Table 6

Cronbach's Alpha Coefficient of internal consistency between the items of each dimension of the study

\begin{tabular}{lll}
\hline Dimension & Number of items & Cronbach Alpha \\
\hline Psychological effects & 14 & 0.937 \\
\hline Educational effects & 16 & 0.853 \\
\hline All items of the dimensions & 30 & 0.940 \\
\hline
\end{tabular}

\section{Data Analysis}

Data was analysed using the following methods within the Statistical Package for Social Sciences (SPSS):

- Simple statistical methods including frequencies, percentages, means, and standard deviations to describe the characteristics of the study sample

- Cronbach Alpha to measure the internal consistency of study variables and dimensions.

- Pearson correlation coefficient to test the validity of the study instrument.

- One Sample T-Test to test the significance of the differences between the mean of the answers and the mean of the hypothetical scale (3), which indicates a neutral score.

- Scheffe's Test was employed to test the significance of differences among the levels of the study variables.

\section{FINDINGS}

Results are presented according to the research questions.

Question one: What is the impact of distance learning on the psychology of university students in Jordan during the Covid-19 pandemic?

To answer this research question, means, standard deviations, rank and degree of agreement were calculated for participant's responses to items of the psychological effects dimension of distance learning. Findings are presented in Table 7. 
Table 7

Means, standard deviations, ranks and degree of agreement of the items of the psychological effects dimension of distance learning

\begin{tabular}{llllll}
\hline $\begin{array}{l}\text { Item } \\
\text { No }\end{array}$ & Item & Mean & SD & \begin{tabular}{c} 
Class \\
\hline 1
\end{tabular} & $\begin{array}{l}\text { Degree of } \\
\text { agreement }\end{array}$ \\
\hline 2 & Distance learning increases my anxiety & 4.38 & 1.00 & 1 & High \\
\hline 3 & Distance learning leads to nervousness & 4.23 & 1.07 & 4 & High \\
\hline 4 & Distance learning leads to depression & 4.05 & 1.18 & 8 & High \\
\hline 5 & Distance learning makes my life empty and boring & 3.91 & 1.25 & 9 & High \\
\hline 6 & Distance learning causes disturbances in my sleep & 4.24 & 1.10 & 3 & High \\
\hline 7 & $\begin{array}{l}\text { I feel that my sensitivity to things has increased due to } \\
\text { distance learning }\end{array}$ & 3.13 & 1.20 & 5 & High \\
\hline 8 & My behavior became emotional due to distance learning & 3.77 & 1.26 & 10 & High \\
\hline 9 & I feel that distance learning has increased my aggressiveness & 3.37 & 1.39 & 13 & High \\
\hline 10 & Distance learning makes me feel frustrated & 4.09 & 1.24 & 7 & High \\
\hline 11 & $\begin{array}{l}\text { Distance learning pushed me to escape the problems of } \\
\text { everyday life }\end{array}$ & 3.00 & 1.30 & 14 & Average \\
\hline 12 & $\begin{array}{l}\text { I feel restless and nervous about distance learning if my } \\
\text { internet subscription ends }\end{array}$ & 4.31 & 1.03 & 2 & High \\
\hline 13 & Ineglected my traditional practices due to distance learning & 4.09 & 1.17 & 6 & High \\
\hline 14 & Ineglected my daily rituals due to distance learning & 3.75 & 1.30 & 12 & High \\
\hline & $\begin{array}{l}\text { The general mean of the items of the psychological effects } \\
\text { dimension }\end{array}$ & 3.94 & 0.89 & High
\end{tabular}

As evidenced in Table 7 the total mean of the psychological effects dimension was 3.94 and all items of the dimension were of a high level of agreement except two items, which were of an average level. Means of the items ranged from 3.00 to 4.38 where item 1 "distance learning has increased my anxiety" ranked first with a mean of 4.38 and a standard deviation of 1.00 indicating a high level of agreement. The second ranked item was 12 "I feel upset and nervous in distance learning if my Internet subscription ends," with a mean of 4.31 and a standard deviation of 1.03 with a high level of agreement. Item 11 "I feel that distance learning pushed me to escape from the problems of daily life," ranked last with a mean of 3.00 , a standard deviation of 1.30 , indicating an average level of agreement.

A One Sample T-Test was performed to determine the significance of the differences between the mean of answers on the psychological effects dimension of distance learning and the mean of the hypothetical scale 3 . Results are presented in Table 8.

Table 8

Results of One Sample T Test to test the presence of negative psychological effects of distance learning

\begin{tabular}{lllllll}
\hline Dimension & Mean & $\begin{array}{l}\text { Scale } \\
\text { mean }\end{array}$ & $\begin{array}{l}\text { Calculated } t \\
\text { value }\end{array}$ & $\begin{array}{l}\text { Tabulated } t \\
\text { value }\end{array}$ & $\begin{array}{l}\text { Degrees of } \\
\text { freedom }\end{array}$ & $\begin{array}{l}\text { Significance } \\
\text { level }\end{array}$ \\
\hline $\begin{array}{l}\text { Psychological } \\
\text { effects of } \\
\text { distance learning }\end{array}$ & 3.94 & 0.89 & 21.373 & 1.972 & 414 & $0.000^{*}$ \\
\hline
\end{tabular}

* The differences are statistically significant at $(\alpha \leq 0.05)$.

Table 8 shows significant differences at the level of $(\alpha \leq 0.05)$ between the total score of the mean of the answers on the scale psychological effects of distance learning and the 
mean score of the hypothetical scale, where the calculated t value was 21.653 . This is higher than the tabulated $t$ value 1.972 with degrees of freedom of 414 and the level of error 0.05 meaning there are negative psychological effects on students due to distance learning during the Covid-19 pandemic.

Question two: What is the impact of distance learning on university students' learning in Jordan during Covid-19 pandemic?

To answer this question, means, standard deviations, rank and degree of agreement were calculated for the responses of the sample members to the items of the impact of distance learning on student's learning dimension. Findings are illustrated in Table 9.

Table 9

Means, standard deviations, ranks and degree of agreement of the items of the educational effects dimension of distance learning

\begin{tabular}{|c|c|c|c|c|c|}
\hline $\begin{array}{l}\text { Item } \\
\text { No }\end{array}$ & Item & Mean & SD & Class & $\begin{array}{l}\text { Degree of } \\
\text { agreement }\end{array}$ \\
\hline 1 & $\begin{array}{l}\text { Distance learning leads to a decrease in my } \\
\text { academic achievement }\end{array}$ & 4.08 & 1.18 & 8 & High \\
\hline 2 & $\begin{array}{l}\text { Distance learning leads to frequent absences from } \\
\text { online lectures }\end{array}$ & 4.17 & 1.11 & 7 & High \\
\hline 3 & $\begin{array}{l}\text { Distance learning leads to poor focus when learning } \\
\text { educational materials }\end{array}$ & 4.33 & 1.03 & 2 & High \\
\hline 4 & $\begin{array}{l}\text { Distance learning leads to my mind wandering and } \\
\text { poor attention }\end{array}$ & 4.30 & 1.07 & 3 & High \\
\hline 5 & Distance learning leads to neglect of my homework & 3.58 & 1.39 & 12 & Average \\
\hline 6 & Distance learning makes me lag my studies behind & 4.21 & 1.14 & 6 & High \\
\hline 7 & I think quizzes in distance learning are unfair & 4.21 & 1.11 & 5 & High \\
\hline 8 & $\begin{array}{l}\text { Distance learning encourages collaborative learning } \\
\text { among students through social media }\end{array}$ & 2.69 & 1.34 & 15 & Average \\
\hline 9 & $\begin{array}{l}\text { Distance learning makes me more dependent on } \\
\text { technology than on teacher in getting information }\end{array}$ & 3.93 & 1.18 & 9 & High \\
\hline 10 & $\begin{array}{l}\text { Distance learning encourages the student to } \\
\text { plagiarize online }\end{array}$ & 3.86 & 1.26 & 10 & High \\
\hline 11 & $\begin{array}{l}\text { Distance learning leads to lethargy and laziness } \\
\text { while attending online lectures }\end{array}$ & 4.46 & 0.92 & 1 & High \\
\hline 12 & $\begin{array}{l}\text { Distance learning made me more dependent on } \\
\text { myself to learn }\end{array}$ & 2.54 & 1.44 & 16 & Average \\
\hline 13 & $\begin{array}{l}\text { Distance learning helped me develop my scientific } \\
\text { research skill }\end{array}$ & 2.93 & 1.35 & 14 & Average \\
\hline 14 & $\begin{array}{l}\text { Distance learning improved my academic } \\
\text { achievement }\end{array}$ & 3.62 & 1.26 & 11 & Average \\
\hline 15 & $\begin{array}{l}\text { I learn better in conventional education (face-to- } \\
\text { face) than in distance education }\end{array}$ & 4.23 & 1.25 & 4 & High \\
\hline \multirow[t]{2}{*}{16} & $\begin{array}{l}\text { If I had enough experience dealing with distance } \\
\text { learning tools, my academic achievement would be } \\
\text { much better }\end{array}$ & 3.27 & 1.34 & 13 & Average \\
\hline & $\begin{array}{l}\text { The general mean of items of the educational effects } \\
\text { dimension }\end{array}$ & 3.78 & 0.68 & & High \\
\hline
\end{tabular}

As illustrated in Table 9 the general mean of the educational effects dimension of distance learning was 3.78, where 10 items were of a high level of agreement and 6 were 
of an average level. Means of the items ranged from 2.54 and 4.46 where item 11 "distance learning leads to lethargy and laziness while attending online lectures" ranked highest with a mean of 4.46 and a standard deviation of 0.92 indicating a high level of agreement. Item 3 "distance learning leads to poor focus when learning educational materials" ranked second with a mean of 4.33 and a standard deviation of 1.03 indicating a high level of agreement. Item 12 "distance learning made me more dependent on myself to learn" ranked last with a mean of 2.54 and a standard deviation of 1.44, indicating an average level of agreement, meaning that distance learning does not lead to an increase in self-reliance.

To test the significance of the differences between the mean of the answers of the educational effects dimension of distance learning and the mean of the hypothetical scale 3, a One Sample T-Test was performed with results presented in Table 10.

Table 10

Results of One Sample T Test to test the presence of negative educational effects of distance learning

\begin{tabular}{llllllll}
\hline Dimension & Mean & $\begin{array}{l}\text { Scale } \\
\text { mean }\end{array}$ & $\begin{array}{l}\text { Calculated } \\
\text { value }\end{array}$ & $\begin{array}{l}\text { Tabulated } \\
\text { value }\end{array}$ & $\begin{array}{l}\text { Degrees of } \\
\text { freedom }\end{array}$ & $\begin{array}{l}\text { Significance } \\
\text { level }\end{array}$ \\
\hline $\begin{array}{l}\text { Educational } \\
\text { effects of } \\
\text { distance learning }\end{array}$ & 3.78 & 0.68 & 23.191 & 1.972 & 414 & $0.000^{*}$
\end{tabular}

* The differences are statistically significant at $(\alpha \leq 0.05)$.

As shown in Table 10 there are significant differences at the level of $(\alpha \leq 0.05)$ between the total mean score of the answers on the educational effects dimension of distance learning and the mean score of the hypothetical scale, where the calculated t value was 23.191 which is higher than the tabulated $t$ value of 1.972 with degrees of freedom of 414 and a level of error of 0.05 . This result means that distance learning negatively affected student's learning during the Covid-19 pandemic.

Question three: Are there significant differences in the psychological effects of distance learning attributable to gender, discipline, GPA, academic year, computer skills and distance learning device?

To answer question three the means and standard deviations of the negative psychological effects of distance learning according to the study variables were calculated with results being presented in Table 11. 
Table 11

Means and standard deviations of the psychological effects of distance learning according to discipline, distance learning device, GPA, academic year, level of computer skills

\begin{tabular}{lllll}
\hline \multirow{2}{*}{ Variable } & & Number & Mean & SD \\
\hline \multirow{3}{*}{ Discipline } & Humanities & 151 & 4.00 & 0.84 \\
\cline { 2 - 5 } & Sciences & 264 & 3.90 & 0.92 \\
\hline \multirow{3}{*}{ GPA } & Computer & 166 & 3.75 & 0.94 \\
\cline { 2 - 5 } & Mobile Phone & 242 & 4.07 & 0.83 \\
\cline { 2 - 5 } & Tablet/iPad & 7 & 3.61 & 1.09 \\
\hline \multirow{3}{*}{ Academic yearning device } & Satisfactory & 40 & 3.89 & 0.94 \\
\cline { 2 - 5 } & Good & 144 & 3.93 & 0.89 \\
\cline { 2 - 5 } & Very good & 186 & 3.99 & 0.89 \\
\cline { 2 - 5 } & Excellent & 45 & 3.76 & 0.87 \\
\hline Computer skill & First & 134 & 4.11 & 0.74 \\
\cline { 2 - 5 } Levels & Second & 100 & 4.12 & 0.81 \\
\cline { 2 - 5 } & Third & 102 & 3.72 & 0.98 \\
\cline { 2 - 5 } & Fourth & 235 & 3.77 & 0.95 \\
\hline & High & 78 & 3.69 & 0.94 \\
\cline { 2 - 5 } & Average & & 4.35 & 0.67 \\
\cline { 2 - 5 } & Low & & & 0.89 \\
\hline
\end{tabular}

To test for differences in the negative psychological effects of distance learning among students according to discipline, distance learning device, GPA, academic year and computer skill levels the analysis of variance (ANOVA) was used. Results are presented in Table 12.

Table 12

Results of the analysis of variance for testing differences in the negative psychological effects of distance learning according to gender, discipline, distance learning device, GPA, academic year, computer skill levels

\begin{tabular}{llllll}
\hline Source of variance & Squares sum & DF & Mean squares sum & F value & P value \\
\hline Gender & 1.019 & 1 & 1.019 & 1.393 & 0.239 \\
\hline Discipline & 0.018 & 1 & 0.018 & 0.024 & 0.877 \\
\hline Distance learning device & 2.542 & 2 & 1.271 & 1.738 & 0.177 \\
\hline GPA & 1.472 & 3 & 0.491 & 0.671 & 0.570 \\
\hline Academic year & 8.761 & 3 & 2.920 & 3.994 & $0.008^{*}$ \\
\hline Computer skill level & 10.137 & 2 & 5.069 & 6.933 & $0.001^{*}$ \\
\hline Error & 293.914 & 402 & 0.731 & & \\
\hline Total & 6757.934 & 415 & & & \\
\hline Modified total & 329.366 & 414 & & & \\
\hline
\end{tabular}

* The differences are statistically significant at $(\alpha \leq 0.05)$.

As evident in Table 12 the results of the analysis of variance did not show significant differences at the level of $(0.05 \geq \alpha)$ in the psychological effects of distance learning due to differences in gender, discipline, distance learning device, and GPA, as the calculated F values were $1.393,0.024,1.738,0.671$ respectively, and their statistical significance was all higher than 0.05 . Whereas, the results of the analysis showed the existence of significant differences at the level of $(0.05 \geq \alpha)$ in the psychological effects of distance learning due to the difference in both the academic year and level of computer skills, as 
the calculated $\mathrm{F}$ values were 3.994, 6.933 respectively, and the significance level of all were below 0.05 .

To test the significance of the differences in the psychological effects of distance learning among academic years and computer skill levels, Scheffe's Test was employed for the posttests. Results are shown in Tables 12 and 13.

Table 13

Results of the analysis of variance for testing the differences in the negative psychological effects of distance learning on students according to the academic year variable

\begin{tabular}{llll}
\hline Academic year & & Mean of variation & Significance level \\
\hline \multirow{2}{*}{ First } & Second & -0.005 & 1.000 \\
\cline { 2 - 4 } & Third & 0.388 & $* 0.030$ \\
\cline { 2 - 4 } & Fourth & 0.340 & 0.078 \\
\hline Second & First & 0.005 & 1.000 \\
\hline & Third & 0.394 & 0.010 \\
\hline Third & Fourth & 0.345 & $* 0.034$ \\
\hline & First & -0.388 & $* 0.030$ \\
\hline Fourth & Second & -0.394 & 0.010 \\
\hline & Fourth & -0.049 & 0.984 \\
\hline & First & -0.340 & 0.078 \\
\hline
\end{tabular}

* The differences are statistically significant at $(\alpha \leq 0.05)$.

As illustrated in Table 13 Scheffe's Test yielded significant differences at the level of 0.05 in the negative psychological effects of distance learning between the first and third year students in favor of those in first year, as well as significant differences between the second and fourth year students in favor of the second-year students.

Table 14

Results of the analysis of variance for testing differences in the negative psychological effects of distance learning among the computer skill levels

\begin{tabular}{llll}
\hline Computer skill levels & & Mean of variation & Significance level \\
\hline High & Average & -0.214 & 0.116 \\
\hline Average & Low & -0.653 & $0.000^{*}$ \\
\hline & High & 0.214 & 0.116 \\
\hline Low & Low & -0.439 & $0.001^{*}$ \\
\hline & High & 0.653 & $0.000^{*}$ \\
\hline
\end{tabular}

* The differences are statistically significant at $(\alpha \leq 0.05)$.

Table 14 shows that Scheffe's Test revealed significant differences at the level of 0.05 in the negative psychological effects of distance learning between students with low skill levels and both average and high computer skill levels in favor of those with low computer skills. 
Question four: Are there significant differences in the educational effects of distance learning attributable to gender, discipline, distance learning device, GPA, academic year and computer skills?

To answer this question the means and standard deviations of the negative educational effects of distance learning according to the study variable were calculated. Results are shown in Table 15.

\section{Table 15}

Means and standard deviations of the negative educational effects of distance learning according to gender, discipline, GPA, academic year, computer skill levels and distance learning device

\begin{tabular}{|c|c|c|c|c|}
\hline Variable & & Number & Mean & Standard deviation \\
\hline \multirow{2}{*}{ Gender } & Male & 124 & 3.82 & 0.76 \\
\hline & Female & 291 & 3.75 & 0.64 \\
\hline \multirow{2}{*}{ Discipline } & Humanities & 151 & 3.80 & 0.64 \\
\hline & Sciences & 264 & 3.76 & 0.70 \\
\hline \multirow{4}{*}{ GPA } & Satisfactory & 40 & 3.81 & 0.65 \\
\hline & Good & 144 & 3.76 & 0.68 \\
\hline & Very good & 186 & 3.84 & 0.69 \\
\hline & Excellent & 45 & 3.53 & 0.66 \\
\hline \multirow{4}{*}{ Academic year } & First & 84 & 3.97 & 0.58 \\
\hline & Second & 130 & 3.84 & 0.61 \\
\hline & Third & 101 & 3.67 & 0.79 \\
\hline & Fourth & 100 & 3.64 & 0.70 \\
\hline \multirow{3}{*}{ Computer skill level } & High & 102 & 3.58 & 0.73 \\
\hline & Average & 235 & 3.75 & 0.70 \\
\hline & Low & 78 & 4.09 & 0.42 \\
\hline \multirow{3}{*}{$\begin{array}{l}\text { Distance learning } \\
\text { device }\end{array}$} & Computer & 166 & 3.65 & 0.71 \\
\hline & Mobile phone & 242 & 3.87 & 0.65 \\
\hline & Tablet/iPad & 7 & 3.35 & 0.57 \\
\hline
\end{tabular}

To test for differences in the negative educational effects of distance learning according to gender, discipline, GPA, academic year, computer skill level and distance learning device the analysis of variance (ANOVA) was used with results being presented in Table 16.

Table 16

Results of the analysis of variance for testing differences in the negative educational effects of distance learning according to gender, discipline, GPA, academic year, computer skill level and distance learning device

\begin{tabular}{llllll}
\hline Source of variance & Squares sum & DF & Mean squares sum & F value & P value \\
\hline Gender & 0.478 & 1 & 0.478 & 1.131 & 0.288 \\
\hline Discipline & 0.027 & 1 & 0.027 & 0.065 & 0.800 \\
\hline GPA & 2.400 & 3 & 0.800 & 1.893 & 0.130 \\
\hline Academic year & 4.768 & 3 & 1.589 & 3.761 & $0.011^{*}$ \\
\hline Computer skill level & 7.110 & 2 & 3.555 & 8.412 & $0.000^{*}$ \\
\hline Distance learning device & 1.394 & 2 & 0.697 & 1.650 & 0.193 \\
\hline Error & 169.892 & 402 & 0.423 & & \\
\hline Total & 6106.977 & 415 & & & \\
\hline Modified total & 192.023 & 414 & & & \\
\hline
\end{tabular}

* The differences are statistically significant at $(\alpha \leq 0.05)$. 
Table 16 shows that the analysis of variance did not reveal significant differences at the level of $(0.05 \geq a)$ in the terms of negative educational effects attributed to gender, discipline, distance learning device and GPA as the calculated F values were 1.131, $0.065,1.650,1.893$ respectively, and their statistical significance level was higher than 0.05 . Whereas, the results of the analysis showed significant differences at the level of $(0.05 \geq \alpha)$ in negative educational effects due to differences in both the academic year and computer skill levels, as the calculated values of $F$ were 3.761 and 8.412 and the statistical significance of all of them below 0.05 .

To test the significance of the differences in the educational effects of distance learning among the academic years and computer skill levels, Scheffe's Test was employed for the posttests. Results are shown in Tables 17 and 18 .

Table 17

Results of the analysis of variance for testing differences in the negative educational effects of distance learning according to the academic year variable

\begin{tabular}{llll}
\hline Academic year & & Mean of variation & Significance level \\
\hline First & Second & 0.125 & 0.623 \\
\hline & Third & 0.298 & $0.030^{*}$ \\
\hline Second & Fourth & 0.327 & $0.013^{*}$ \\
\hline & First & -0.125 & 0.623 \\
\hline & Third & 0.173 & 0.288 \\
\hline Third & Fourth & 0.202 & 0.165 \\
\hline & First & -0.298 & $0.030^{*}$ \\
\hline Fourth & Second & -0.173 & 0.288 \\
\hline & Fourth & 0.029 & 0.993 \\
\hline & First & -0.327 & $0.013^{*}$ \\
\hline & Second & -0.202 & 0.165 \\
\hline
\end{tabular}

* The differences are statistically significant at $(\alpha \leq 0.05)$.

As presented in Table 17 Scheffe's Test showed significant differences at the level of 0.05 in the negative educational effects of distance learning among first, third and fourth year students in favor of first year students.

Table 18

Results of the analysis of variance to test differences in the negative educational effects of distance learning according to the computer skill levels variable

\begin{tabular}{llll}
\hline Computer skill level & & Mean of variation & Level of significance \\
\hline \multirow{2}{*}{ High } & Average & -0.168 & 0.101 \\
\cline { 2 - 4 } & Low & -0.511 & $0.000^{*}$ \\
\hline \multirow{2}{*}{ Average } & High & 0.168 & 0.101 \\
\cline { 2 - 4 } & Low & -0.342 & $0.000^{*}$ \\
\hline \multirow{2}{*}{ Low } & High & 0.511 & $0.000^{*}$ \\
\cline { 2 - 4 } & Average & 0.342 & $0.000^{*}$ \\
\hline
\end{tabular}

* The differences are statistically significant at $(\alpha \leq 0.05)$.

Table 18 shows that Scheffe's Test revealed significant differences at the level of 0.05 in negative educational effects of distance learning between students with low computer skills and those with high and average skills in favor of students with low level of skills. 
Question five: Is there a relationship between students' psychology and learning in distance learning during the Covid-19 pandemic?

To answer the question Pearson product-moment correlations were calculated between the psychological effects scores and educational effects scores of distance learning. The result is shown in Table 19.

Table 19

Correlation between the negative educational effects and the negative psychological effects of distance learning

\begin{tabular}{cll}
\hline \multicolumn{1}{c}{ Variable } & & Psychological effects \\
\hline \multirow{2}{*}{ Educational effects } & Pearson coefficient & 0.765 \\
\cline { 2 - 3 } & Significance level & $* 0.000$ \\
\hline
\end{tabular}

* The differences are statistically significant at $(\alpha \leq 0.05)$.

It is noted from Pearson correlation coefficient that there is a significant correlation at the level of $(0.0 .1 \geq \alpha)$ between students' psychology and their learning in distance learning, where the value of the Pearson correlation coefficient was $(0.765)$. This result means that students' learning was affected by their psychological state in distance learning during the Covid-19 pandemic.

\section{DISCUSSION}

One of the main questions raised in this research was whether distance learning had any effect on the psychology of university students during the Covid-19 pandemic. The results have revealed a high degree of agreement among students on the presence of negative psychological effects of distance learning during this time. That is, students indicated that distance learning made them feel anxious, restless and nervous. In addition, students indicated that learning at a distance made them also feel confused and depressed. This result lends support to other previous studies (e.g., Ajmal \& Ahmad, 2019; $\mathrm{Li}$ et al., 2020) which explored distance learning and found that the level of anxiety among students engaged in distance learning was higher than conventional students.

The above result is not unexpected, as students were required to suddenly leave their face-to-face learning to transfer to distance learning without any prior experience or training. Akther (2013) asserts that the use of distance learning requires students to have a high level of autonomy and self-organization, which perhaps the students in the current study may have lacked. In addition, being quarantined meant that students were away from their friends and peers which added further anxiety and distress. This result is consistent with other studies (e.g., Irawan, Dwisona, \& Lestar, 2020; Lischer, Safi., \& Dickson, 2021; Li et al., 2020; Wang et al., 2020) which showed elevated levels of anxiety, distress, and depression among individuals who were quarantined.

In addition, switching to distance learning without fully using unitary LMS platforms forced instructors, especially those who were not trained to use such platforms, to use different soft online communication tools (e.g., Facebook, Messenger, WhatsApp) to 
connect with their students and deliver instruction. The use of this variety of tools perhaps was difficult for students to manage, making them feel restless and confused.

Also, the lack of face-to-face interaction, missing online classes, numerous tasks, and Internet connection problems may have left these students feeling more anxious and frustrated. Additionally, being at home most of the time during the quarantine meant an inability to socialize with friends, which potentially left students feeling bored and depressed. Dzakiria, Idrus, and Atan (2005) argue that an important instructional element of online distance learning is interaction. That is, a high level of interaction is found to positively affect the psychology of students impacting on the effectiveness of their distance learning.

Furthermore, the results of the current study showed significant differences in the negative psychological effects of distance learning between first and third-year students in favor of those in first-year, as well as significant differences between second and fourth-year students in favor of second-year students. This means that freshman students had higher negative psychological effects and higher levels of anxiety, depression, and confusion than students in year three or four. It is possible that freshman students are less experienced with university education, are unfamiliar with online learning, and cannot manage independent learning thus resulting in them feeling more anxious and worried.

Moreover, the current study showed significant differences in the negative psychological effects of distance learning between students with low computer skills and both average and high computer skills in favor of those with low computer skills. It seems that having adequate computer skills and knowledge enabled students to better manage their online learning, and cope with technical difficulties as they arose which subsequently eased their anxiety and nervousness; something that appeared to be lacking in those with low computer skills.

The other important question in this research was whether distance learning had any effect on university student's learning during the Covid-19 pandemic. The results showed a high degree of agreement among students that distance learning negatively effected their learning. That is, students indicated that distance learning resulted in lethargy and laziness while attending online lectures caused poor concentration which resulted in poor academic achievement. Furthermore, students indicated that they learn better in face-to-face contexts than using distance education. This result is not surprising since the learning material offered online was never designed within the framework of distance learning; instead, it aimed to compensate for the absence of face-to-face classrooms with online classes without adequate preparation. In addition, conventional students were not accustomed to distance learning and the lack of interaction and selfregulation skills required which potentially impacted on their engagement. Also, because of the lack of experience with teaching online, instructors were unable to introduce highquality interactive teaching, leaving students feeling uninterested in learning from a distance. 
Furthermore, the results showed significant differences in the level of negative educational effects of distance learning due to differences in the academic year. That is, there were significant differences among first, third and fourth academic year students in favor of those in their first year. In other words, first-year students' learning was negatively affected more by distance learning than students did in either third or fourth year. This is most likely because first-year students are not yet accustomed to university education and being distant from teachers and peers during the Covid-19 pandemic made it difficult for them to manage their learning on their own; suggesting a need to support first-year students to be more autonomous. Students who were in their final academic years were more familiar with the educational environment of the university and seemingly had adequate skills in managing their learning. Also, distance learning requires more discipline and commitment on the part of the student, and perhaps students in their early academic years lacked this discipline and commitment, which potentially negatively impacted their learning.

The results showed significant differences in the negative educational effects of distance learning between students with low computer skills and those with high and average skills in favor of the students with low skill levels. It seems that students with average and high computer skills were better able to manage their online learning and cope with any technical problems might face than those with low computer skills. They appeared to have the knowledge of how to manage various online learning tools, which subsequently assisted them to do well in their studies. This result suggests that courses should be designed to develop students' computer skills so that they can manage their learning and show positive attitudes towards online learning (Li \& Lee, 2016)

Finally, results showed a significant correlation between students' psychology and their learning in distance learning. That is, students' learning was negatively affected by their psychological state in distance learning during the Covid-19 pandemic. This finding is consistent with previous studies, which demonstrated that psychological factors such as stress, anxiety, depression, lack of motivation, loneliness, and helplessness negatively affected students' academic achievement (Ajmal \& Ahmad, 2019; Beharu, 2018; Mundia, 2011). The psychological factors accompanying distance learning during the Covid-19 pandemic perhaps affected students learning negatively. This result suggests that student's psychology should be considered when planning distance learning as a positive psychology is evidenced to help them achieve and even improve their academic achievement.

\section{CONCLUSION AND RECOMMNADATIONS}

In conclusion, it is apparent from the findings of the current study that learning from a distance and being quarantine during the Covid-19 pandemic had a negative impact on the psychology and learning of the university students in this study who were forced, in a short period of time, to switch from face-to-face learning to distance learning. It is acknowledged that the success and failure we experience in our life depends on our psychological state (Bryant, 2017) thus experience poor psychology can lead distancelearning students during the Covid-19 pandemic to struggling with their academic 
achievements, experience poor performance, and low self-confidence. Therefore, in line with these findings the following recommendations are devised:

- Academic staff and students should be given training courses to learn how to effectively use online learning applications and LMS tools. They should be provided with technical assistance and support when needed by eLearning centres.

- Psychological counselling and academic advice should be given to students to reduce and ease the negative effects of distance learning on their psychology and learning.

- Student's psychology should be considered when planning for distance learning as this will help them do well in their learning and improve their academic achievement.

- Academic staff should adapt and master the latest teaching strategies for distance learning such as using a mix of learning tools, group work, various types of content (e., text, video, PowerPoint presentations, ongoing feedback, engaging activities, providing multiple of resources, online discussion) for better engagement. It is also necessary for academic staff to plan activities where students can engage with each other online as part of their learning tasks.

- This research was conducted during the second month of moving to distance learning at the University of Petra. More research is needed to further examine students' and lecturer's perspectives on distance learning amid the Covid-19 pandemic especially after new measures and regulations were implemented by universities.

- The data of the current study were taken from one university, the University of Petra. To get a clearer picture of the impact of distance learning on students' psychology and learning, future research should look at more universities and include those students who already study online as well as those who do not.

Finally, it is hoped that the findings of the current study can provide policymakers and professionals in education with valuable information on the impact of distance learning on the psychology and learning of students amid the Covid-19 pandemic. This may assist them in taking precautions and making preparations for possible future outbreaks of novel spreadable diseases. In addition, policy needs to address professional development for faculty to ensure that the best online learning experiences are offered to students.

\section{REFERNCES}

Adnan, M., \& Anwar, K. (2020). Online learning amid the COVID-19 pandemic: Students' perspectives. Journal of Pedagogical Sociology and Psychology, 2(1), 45-51. http://www.doi.org/10.33902/JPSP

Ahmad, N., \& Al-Khanjari, Z. A. (2011). Effect of Moodle on learning: An Oman perception. International Journal of Digital Information and Wireless Communications, 4, 782-788. 
Ajmal, M., \& Ahmad, S. (2019). Exploration of anxiety factors among students of distance learning: A case study of Allama Iqbal Open University. Bulletin of Education and Research, 41(2), 67-78.

Akther, U. M. (2013). Psychological impact of distance education technologies in students' personal development. International Journal of Developmental and Educational Psychology, 2(1), 203-211.

Ali, A., \& Ahmad, I. (2011). Key factors for determining students' Satisfaction in distance learning courses: A study of Allama Iqbal Open University. Contemporary Educational Technology, 2(2), 118-134.

Attri, A. K. (2012). Distance education: Problems and solutions. International Journal of Behavioral Social and Movement Sciences, 1(4), 42-58.

Beharu, W. T. (2018). Psychological factors affecting students academic performance among freshman psychology students in Dire Dawa University. Journal of Education and Practice, 9(4), 58-65.

Britt, R. (2006). Online education: A survey of faculty and students. Radiologic Technology, 77(3), 183-190.

Bryant, B. (2017). Learning from success and failure. Research \& Knowledge. Retrieved December 20, 2020, from https://www.imd.org/researchknowledge/articles/learning-from-success-and-failure/

Carvalho, A., Areal, N., \& Silva. J. (2010). Students' perceptions of Blackboard and Moodle in a Portuguese university. British Journal of Educational Technology, 42(5), $824-841$

Cucinotta D, Vanelli M. (2020). WHO declares COVID-19 a pandemic. Acta Biomed, 91(1), 157-160. doi: 10.23750/abm.v91i1.9397.

Crawford, J., Butler-Henderson, K., Jurgen, R., Malkawi, B., Glowatz, M., Burton, R., Magni, P., \& Lam, S. (2020). COVID-19: 20 countries' higher education intra-period digital pedagogy responses. Journal of Applied Learning \& Teaching, 3(1), 1-19. DOI: $10.37074 /$ jalt.2020.3.1.7

Dhawan, S. (2020). Online learning: A panacea in the time of COVID-19 crisis. Journal of Educational Technology Systems, 49(1), 5-22. doi: 10.1177/0047239520934018

Dodo, O. (2013). An analysis of challenges faced by students learning in virtual and open distance learning system: A case of Bindura University of Science Education (BUSE). Journal of Global Peace and Conflict, 1(1), 28-40.

Dzakiria, H., Idrus, R. M., \& Atan, H. (2005). Interaction in open distance learning: Research issues in Malaysia. Malaysian Journal of Distance Education, 7(2), 63-77.

Elmer, T., \& Stadtfeld, C. (2020). Depressive symptoms are associated with social isolation in face-to-face interaction networks. Sci Rep 10, 1444. https://doi.org/10.1038/s41598-020-58297-9 
Giovannella, C. (2021). Effect induced by the Covid-19 pandemic on students' perception about technologies and distance learning. In Mealha, O., Rehm. M., Rebedea, T. (eds) Ludic, co-design and tools supporting smart learning ecosystems and smart education. Smart Innovation, Systems and Technologies, vol 197. Springer, Singapore. https://doi.org/10.1007/978-981-15-7383-5_9

Irawan, A., \& Dwisona, D., \& Lestari, M. (2020). Psychological impacts of students on online learning during the pandemic COVID-19. KONSELI : Jurnal Bimbingan dan Konseling (E-Journal), 7, 53-60. 10.24042/kons.v7i1.6389.

Li, H. Y., Cao, H., Leung, D. Y.P., \& Mak, Y. W. (2020). The psychological impacts of a COVID- 19 outbreak on college students in China: A longitudinal study. International Journal of Environmental Research and Public Health, 17(11), 3933. DOI: $10.3390 /$ ijerph17113933

Li, L-Y., \& Lee, L-Y. (2016). Computer literacy and online learning attitude toward GSOE students in distance education programs. Higher Education Studies, 6(3).

Lischer, S., Safi, N., \& Dickson, C. (2021). Remote learning and students' mental health during the Covid-19 pandemic: A mixed-method enquiry. Prospects. https://doi.org/10.1007/s11125-020-09530-w

Mailizar, M, Almanthari, A., \& Maulina, S., \& Bruce, S. (2020). Secondary school mathematics teachers views on eLearning implementation barriers during the covid-19 pandemic the case of Indonesia. Eurasia Journal of Mathematics, Science and Technology Education, 16(7). em1860.

Mantasiah, R., Yusri., Sinring, A., \& Aryani, F. (2021). Assessing verbal positive reinforcement of teachers during school from home in the Covid-19 pandemic era. International Journal of Instruction, 14(2), 1037-1050.

Moawad, R. A. (2020). Online learning during the COVID- 19 pandemic academic stress in university students. Revista Romaneasca pentru Educatie Multidimensionala, 12(1Sup2), 100-107.

Mundia, L. (2011). Effects of psychological distress on academic achievement in Brunei Student Teachers: Identification challenges and counseling implications. Higher Education Studies, 1(1), 51-63

Musingafi, M. C.C., Mapuranga, B., Chiwanza, K., \&., Zebron. S. (2015). Challenges for open and distance learning (ODL) students: Experiences from students of the Zimbabwe Open University. Journal of Education and Practice, 6(18), 59-66.

Oliveira, P., Cunha, C., \& Nakayama, M. (2015). Learning management systems (LMS) and e-learning management: an integrative review and research agenda. Journal of Information Systems and Technology Management, 13(2), 27-44.

Prokopenko, I., \& Berezhna, S. (2020). Higher education institutions in Ukraine during the Coronavirus, or COVID-19, Outbreak: New challenges vs new opportunities. 
Revista Romaneasca pentru Educatie Multidimensionala, 12(1Sup2), 130-135. Retrieved December 5, 2020, from: https://doi.org/10.18662/rrem/12.1sup1/256

Serrieh, J. (2020). Jordan confirms first coronavirus case: Health ministry. Al Arabiya English. $\quad$ Retrieved November 12, 2020, from: https://english.alarabiya.net/en/News/middle- east/2020/03/02/Jordan-confirms-firstcoronavirus-case-Jordan-News-Agency

Sharath A. M. (2014). The challenges of distance learning education system in karnataka state for higher level education. Nitte University, Fourth International Conference on Higher Education: Special Emphasis on Management Education, December 29-30 2014. Retrieved December 10, 2020, from: https://papers.ssrn.com/sol3/papers.cfm?abstract_id=2600943

Sun, L., Tang, Y., \& Zuo, W. (2020). Coronavirus pushes education online. Natural. Materials. 19(6), 1-1. https://doi.org/10.1038/s41563-020-0678-8

Uddin, A. (2013). Psychological impact of distance education technologies in student's personal development. International Journal of Developmental and Educational Psychology INFAD Revista de Psicología, 1(2), 203-212.

UNESCO. (2020). COVID-19 and higher education: Today and tomorrow: Impact analysis, policy responses and recommendations. Retrieved November 27, 2020, from: https://www.iesalc.unesco.org/en/wp-content/uploads/2020/05/COVID-19-EN130520.pdf

UNESCO. (2020). Distance learning solutions. Retrieved November 17, 2020, from: http://alexmedia.forumsmotions.com/t150-

topichttps://en.unesco.org/covid19/educationresponse/solutions

Wang, C., Pan, R., Wan, X., Tan, Y., Xu, L., Ho, C. S., et al. (2020). Immediate psychological responses and associated factors during the initial stage of the 2019 coronavirus disease (COVID-19) epidemic among the general population in China. International Journal of Environmental Research and Public Health, 17(5), 1729.

Yıldız, E., Tezer, M., \& Uzunboylu, H. (2018). Student opinion scale related to Moodle LMS in an online learning environment: Validity and reliability study. International Journal of Interactive Mobile Technologies (iJIM), 12(4), 79-107. DOI: $10.3991 /$ ijim.v12i4.9205

Zainuddin, N., Idrus, R., \& Jamal, A. F. (2016). Moodle as an ODL teaching tool: A perspective of students and academics. Electronic Journal of e-Learning, 14(4), 2016282. 